\section{ROBERT KOCH}

\section{FOUNDER OF MODERN BACTERIOLOGY}

A HUNDRED years ago, on December 11, 1843 , Robert Koch was born. To celebrate his sixtieth birthday, his pupils, among whom were Ehrlich, Gaffky, Loeffler, Pfeiffer, Flügge, Gaertner and Wassermann, arranged a F'estschrift in his honour and boldly dedicated it to him as the founder of modern bacteriology. A brief review of Koch's life and work will help us to judge whether he is entitled to this distinction and to estimate the significance of his work in the subsequent evolution of the subject.

Without doubt the early period of Koch's career is unsurpassed in dramatic interest, for as an unknown young practitioner in Wollstein, a little out-of-theway town in Prussia, he carried on his researches, unaided and with the simplest equipment, to such purpose that in 1876-78 he had published three papers, two of which are acknowledged to be classics. He showed for the first time that anthrax is an infective disease caused by a specific bacillus with well-defined characters, and that it is reproducible at will by injecting pure cultures into susceptible animals. There is little wonder that Cohn, who was then professor of botany in Breslau, and Cohnheim, the eminent pathologist, both of them keenly interested in the fundamental but apparently insoluble problems presented by micro-organisms and their relationship to disease, were deeply impressed and were generous in helping Koch to devote his brilliant gifts to the service of humanity. Koch's researches on anthrax were published in 1876 in Cohn's journal, Beiträge zur Biologie der Pflanzen. A master of technique, he published a paper in 1877 on his methods. His studies on the etiology of wound infections appeared in 1878; he showed that, when bacteria in putrid fluids are passaged serially through mice or rabbits, the pathogenic varieties can be obtained post-mortem in pure culture and that the lesions are characteristic of the associated bacteria. Koch's interest in the subject doubtless arose from his experiences as an army doctor in the Franco-Prussian War (1870-71). He gave experimental support in this paper to Lister's antiseptic methods, but was unable from lack of clinical material to carry his researches further. The answer was soon supplied (1880-83) in the remarkable contributions of Alexander Ogston, later professor of surgery in the University of Aberdeen, who clearly defined the role of the micrococci in inflammation, and distinguished between Staphylococcus, as he named it, and Streptococcus (Billroth).

A wider field was opened to Koch when, in 1880, he was attached to the Imperial Department of Health in Berlin, where he worked on methods of sterilization and of testing disinfectants. He had quickly realized that, until a simple method of isolating bacteria in pure culture was evolved, progress would be seriously hampered. Methods such as Lister's dilution procedure were too much influenced by chance, and Koch therefore bent his energies towards devising a solid medium, finally utilizing gelatine, which had previously been employed for the culture of fungi, as a solidifying substance; later, agar proved to be more generally useful owing to its special properties. He demonstrated his methods of obtaining pure cultures at the International Congress of Medicine of 1881 in the Physiological Laboratory of King's College, London, with Lister, and Pasteur in the audience.
During the early years in Berlin, Koch was fortunate in his chief assistants, Gaffky and Loeffler, who, like himself, were accurate and untiring workers. Within ten or twelve years they, with other pupils of Koch, discovered the causal agents of many important infectious diseases of man.

Koch's discovery in 1882 of the tubercle bacillus, his proof by animal experimentation with pure cultures that it is the cause of tuberculous diseases, and his employment in 1890 of tuberculin as a diagnostic and therapeutic agent, brought him worldwide fame, although the premature publication of his work with tuberculin proved, for a time at least, to have unfortunate results. Again, in 1900 he raised the question of the non-identity of the human and bovine types of the tubercle bacillus, and seemed to be unduly rash in proclaiming his belief that the pathogenic role of the bovine bacillus in man is negligible. Nevertheless, the provocative statement of his views led to an enormous amount of work on the subject in many countries, and perhaps chiefly in Great Britain. At the present time, Koch's old tuberculin has proved to be a valuable reagent and is still extensively used in both medical and veterinary practice. Work on the preparation of a highly purified and stable product based on biochemical analysis continues. The characters of the human and bovine types have now been satisfactorily determined, and it is agreed that in some localities the bovine type can produce the pulmonary form of tuberculosis in a high proportion of cases. The problem of the pasteurization of milk for human consumption bristles with difficulties of a practical kind, but their solution is certain to follow adequate and widespread appreciation among the general public of the issues that are involved.

Koch, in spite of his interest in laboratory technique, took no narrow view of the implications of his work. On the contrary, he well understood that his methods were essential as tools, together with the observations of the hygienist and the epidemiologist, for revealing the obscure paths of infection in outbreaks of disease. Thus on November 28, 1902, in Berlin he gave an address which serves as a landmark in the history of epidemics of enteric fever. His thesis was that the patient or convalescent who continues to harbour the specific germ is the chief source of the infection. At his instigation specially organized laboratories were stationed in the typhoidridden localities of Germany, with results which led to a notable reduction in the incidence of the disease and which shed much light on the carrier state.

Koch pursued his researches in many lands. In the years between 1896, at the age of fifty-three, and 1906, he studied sleeping sickness and malaria in Africa, in addition to rinderpest, East Coast fever, and piroplasmosis in cattle: in 1883 he had discovered the cholera vibrio from his investigations in Egypt and India; he was the head of the German plague commission in India; he worked on malaria in Rome; and he advised on anti-malarial measures in New Guinea. This brief statement of the range of his activities shows that he was a microbiologist of wide experience.

Much progress has been made in the thirty years since Koch's death on May 27, 1910, and there have been new and productive lines of research. Thus the related science of immunology has advanced at many points; and the participation of chemists and physicists in the study of bacterial bionomics, in the widest sense of this term, has been a most welcome 
feature of recent work, and has illuminated many hitherto obscure problems in bacterial nutrition and bacterial metabolism in general. The fresh edifice has been solidly built upon the sound foundations that were laid by Robert Koch nearly seventy years ago. He was truly a master-builder in the domain of science, and it is a sinister and indeed a terrifying aspect of the character of the German people that, owing to ill-founded racial prejudice, their notorious anti-semitic Press should have stooped to disown him, on the ground not that he was a Jew-for this he was not-but that he was a Judenknecht, who chose for his intimates such members of the 'hated race' as Cohn, Cohnheim, Weigert and Paul Ehrlich. Detraction of this kind cannot disturb the estimates that have been formed of Koch and his distinguished friends and supporters by the rest of the world, which owes and will ever continue to owe an immense debt of gratitude to these great pioneers of a new science.

G. F. Petrie.

\section{THE RECENT EARTHQUAKE IN TURKEY BY ERNEST TILLOTSON}

$\mathrm{E}$ ARLY on November 27, 1943 (local time), another very strong earthquake occurred in the region east of Ankara between central Anatolia and the Black Sea coast. The earthquake caused much damage in the towns and villages of Samsun, Osmanjik, Tokat, Herek, Ordu, Amasia and Kastamuni. 1,439 buildings have been reported wrecked and 1,570 damaged, and damage was done to roads, railways and telegraph lines. On November 30 the Ankara radio stated that the deaths caused by the earthquake numbered 2,919. Many thousands more were injured.

At Istanbul Observatory the pulses were so violent that the seismograph was unhinged. At Kew Observatory on November 26, a very strong earthquake was recorded by the north-south, east-west and vertical component seismographs. On the vertical component the primary wave registered impulsively at $22 \mathrm{~h}$. $26 \mathrm{~m}$. 08s. U.T. and a further $i P$ pulse registered on all three components at $22 \mathrm{~h} .26 \mathrm{~m}$. 15s. U.T. The maximum ground amplitudes at Kew were: on the vertical component, $960 \mu$ at $22 \mathrm{~h}$. $35 \mathrm{~m}$. $47 \mathrm{~s}$. U.T. with a period 25 ; on the north-south component, $1040 \mu$ at $22 \mathrm{~h}$. $42 \mathrm{~m}$. 35s. U.T. with a period 24 ; and on the east-west component, $1120 \mu$ at $22 \mathrm{~h} .46 \mathrm{~m}$. 13s. U.T. with a period 25. From a preliminary interpretation of the seismogram the epicentral distance from Kew is estimated to have been $2,970 \mathrm{~km}$., which would be consistent with an epicentre in Anatolia.

From the above evidence it would appear that the epicentre was very close to lat. $4 \mathrm{I} \cdot 1^{\circ} \mathrm{N}$., long. $35^{\circ} \mathrm{E}$., which is north of Corum and half way between Amasya and Kastamanu, and west of the Black Sea port of Samsun in Anatolia, Turkey. The time of origin of the shock would be near $22 \mathrm{~h}$. 20.5m. U.T. on November 26 , or $0 \mathrm{~h}$. $40.5 \mathrm{~m}$. local time on November 27. It appears that the earthquake may have had an epicentral region occasioned by extensive faulting rather than a point epicentre; but if, for purposes of calculation, it is desired to envisage a point focus, this would seem to have been rather deeper than normal.
Strong earthquakes have occurred in this and adjoining regions as follow: 330 B.C., Niksar ; A.D. 343, Niksar ; 366, Niksar ; 499, Niksar and Amasya ; 1509, Çorum ; 1754, Sivas ; 1826, Erbaa; 1827, Tokat; 1875, Niksar, Bereketli ; 1877, Mesudiye, Çavdar, Lâdik, Erbaa, Efte ; 1890, Niksar ; 1895, Çavdar ; 1897, Efte ; 1899, Erbaa ; 1904, S.. Karahisar ; 1906, Reşadiye; 1908, Alucra; 1909, S. Karahisar ; 1911, Mesudiye ; 1913, Reşadiye, Niksar, Almus ; 1914, Erbaa, Lâdik ; 1919, Almus ; 1937 , Alucra; and 1938, Kirşehir. But by far the greatest occurred on December 27, 1939, at Erzincan (NATURE, January 6, 1940, p. 13). This latest earthquake mentioned was the forerunner of numerous other smaller shocks which happened throughout the remainder of December 1939 and January 1940, and then major ones on April 14, 1940, July 30, 1940, September 12, 1941, November 12, 1941, a swarm throughout November and December 1941, December 21, 1942, and on June 20, 1943, at Adapazar when 1,304 people lost their lives. Most of these have been mentioned in the "News and Views" columns of NATURE, and there have been scores of smaller shocks at intermediate times from the same epicentral region east and north-east of Ankara.

The present earthquake, though violent, appears to be one of the series which began on December 27, 1939. It exemplifies a well-established observational fact that earthquakes tend to recur in a region once affected. Whether this is due to the persistence of regional earth-forces and lines of crustal weakness, whether it is due to elastic afterworking in the subcrustal layers of the earth, or to the readjustment of crustal blocks following a large-scale block-faulting movement, is not yet established. One or more of these may be important, and in particular cases other factors may be fundamental, but whatever the cause, it is instructive in view of acknowledged recurrence to examine past examples.

On April 19, 1938, at about $13 \mathrm{hr}$., an earthquake occurred in the region of Kirşehir, a village some $140 \mathrm{~km}$. south-east of Ankara. The zone most affected was between the Delice Irmak in the north-east, the Kilic Ozü in the north-west, the route from Kirsehir to Ankara in the south-west and the depression formed by the Sife Gölü in the south-east*. In the surrounding villages and towns the following percentages of houses were destroyed : Aci, 85 per cent ; Efendiköy, 82 per cent; Koçbeyli, 82 per cent; Ceritobasi, 81 per cent, and in other villages smaller proportions. The epicentral region enclosed within isoseismal 10 was elongated from north-west to south-east. The principal permanent movement occurred horizontally along a fault, the southerly portion being displaced to the north-west relatively to the northerly portion for throws ranging from 30 to $100 \mathrm{~cm}$. The move. ment along this fault of Akpinar is aligned with orogenic movement in the region since Mesozoic times, but whether the movement was due to dying or growing earth-forces is not known.

The earthquake of December 27, 1939, at $2 \mathrm{hr}$. (Erzincan) which caused the deaths of some 35,000 people had an epicentral zone stretching from Erzincan to Amasya and from Carsamha to Artova, an area roughly rectangular in shape, $360 \mathrm{~km}$. by $\mathrm{l}^{\prime 2} 2 \mathrm{~km} . \dagger$. The towns and villages most affected

* Ed. Paréjas-Hamit N. Pamir, "Le Tremblement de terre du 19 Avril 1938 en Anatolie central". Publications de l'Institut de Géologie de l'Université d'Istanbul, No. 5, Nouvelle Série, Février 1940. t Ed. Paréjas, I. H. Akyol, E. Altinli. "Le tremblement de terre

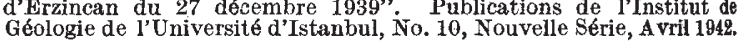

